\title{
EFFECTS OF HIGH TEMPERATURE ON YIELD, QUALITY AND PHYSIOLOGICAL COMPONENTS OF EARLY RICE
}

\author{
Jun Yang ${ }^{1,2}$, Xiaorong Chen ${ }^{1}$, Changlan Zhu' ${ }^{1}$, Xiaosong Peng ${ }^{1}$, Xiaopeng He', Junru Fu², \\ Jianmin Bian², Lifang $\mathrm{Hu}^{2}$, Linjuan Ouyang ${ }^{2}$ and Haohua $\mathrm{He}^{1}$,* \\ ${ }^{1}$ Jiangxi Institute of Meteorological Science, Jiangxi Meteorological Bureau, Nanchang 330096, China; ${ }^{2}$ Key \\ Laboratory of Crop Physiology, Ecology and Genetic Breeding, Ministry of Education, College of Agronomy, \\ Jiangxi Agricultural University, Nanchang 330045, China \\ "Corresponding author's e-mail: hhhua64@163.com, 573286952@qq.com
}

\begin{abstract}
High temperature negatively impacts rice production, and the heat-tolerant cultivars could improve the resistance to high temperature stress. In the present study, six rice varieties were exposed to high temperatures stress $\left(35^{\circ} \mathrm{C}\right.$ and $\left.38^{\circ} \mathrm{C}\right)$ for 3 days during the early filling stage. The differences among two high-temperature treatments were analyzed in terms of yield components, grain quality and physiological parameters of rice. The results showed that high temperature decreased seed setting rate, 1000-grain weight, plumpness, single plant yield, brown rice rate, milled rice rate and amylose content while increased unfilled grain rate of all rice varieties compared with the control. However, the yield components of different rice varieties in response to high temperature exhibited significant genotypic differences. In addition, the influence of high temperature on the hybrid rice variety Jinyou 402 was greater than that on Ganxin203, and the influence of high temperature on the conventional rice variety E134 was greater than that on Zhong531. The $38^{\circ} \mathrm{C}$ treatment was more damaging to early rice than the $35^{\circ} \mathrm{C}$ treatment. Meanwhile, the influences of high temperature on the physiological parameters of flag leaves were consistent with the influence on yield components and grain quality.

Keywords: amylose content, early filling stage, high temperature, rice, seed setting rate.
\end{abstract}

\section{INTRODUCTION}

Rice (Oryza sativa L.) is a major cereal crops for nearly half of the world population in terms of direct consumption, especially in Asia (Cantrell and Reeves, 2002). Rice cultivation is highly vulnerable to natural environment deterioration and global warming (Peng et al., 2004; Mohammed and Tarpley, 2009a; Kim et al., 2013; Ray et al., 2015; Rahman et al., 2017). Air temperature was predicted to increase in the future due to climate change, which could decrease rice productivity (Walbot, 2011). Most rice production comes from tropical regions wherein high temperature is a major constraint to the sustainable food security, especially when extreme temperature coincides with critical stages of plant growth and development (Jagadish et al., 2007; El-Kereamy et al., 2012; Schiermeier, 2015).

Rice yield and quality were declined when high temperature coincides with the grain filling stage (Yamakawa et al., 2007; Mitsui et al., 2013). High temperature stress during the grain filling stage resulted in a decreased grain size, grain weight, poor milling quality, low amylose content, and an increased degree of chalkiness in rice (Morita et al., 2005; Yamakawa and Hakata, 2010; Madan et al., 2012). High temperature stress caused physiological damage to rice plants with a reduced light perception, enzymatic activity, and carbohydrate metabolism, which decreased rice yield and quality (Cooper et al., 2008; Han et al., 2009).

High temperature negatively impacts rice production, and the heat-tolerant cultivars could improve the resistance to high temperature stress. Compared to the non-heat resistant varieties, heat-tolerant Indica rice N22 and IR64 showed significant spikelet fertility (Prasad et al., 2006; Jagadish et al., 2010; Madan et al., 2012). It was reported that the decrease ration of grain weight and net photosynthetic rate in the heat-sensitive line (XN0437S) decreased far more than in the heat-tolerant line (XN0437T) under high temperature (Liao et al., 2014). However, the specific differences under high temperature are not synthetically analyzed with more evidence. Considering recent global warming, understanding the physiological processes underlying this decrease is of great importance. Meanwhile, comprehending the mechanisms by which rice responds to heat stress will facilitate the development of heat-tolerant cultivars with improved productivity under warmer global climates. The overall objective of this study was to quantify comprehensively the effects of high temperature on physiological parameters to provide a theoretical basis for high-temperature tolerant rice breeding. 


\section{MATERIALS AND METHODS}

Plant material: Four early rice varieties (Oryza sativa sp. indica), the two hybrid rice varieties Ganxin203 (RongfengA / R3) and Jinyou402 (Jin23A / R402), and the two conventional rice strains (referred to as variety in the study) Zhong531 and E134 with stable characteristics were used as experimental materials.

Crop husbandry: The trials were performed from March to August (2011 and 2012, experimental data taken from 2012) in a net house at the science and technology park of Jiangxi Agricultural University (latitude: $28^{\circ} 46^{\prime} \mathrm{N}$, longitude: $115^{\circ}$ 50' E, altitude: $48.80 \mathrm{~m}$ ), Nanchang, China. The seeds were selected before sun drying, sterilized with hydrogen peroxide and soaked in tap water. The seeds were germinated inside a plant incubator at $28^{\circ} \mathrm{C} / 24^{\circ} \mathrm{C}(12 \mathrm{~h}$ day / $12 \mathrm{~h}$ night cycles $)$ for $3 \mathrm{~d}$ and were sown by hand on March 15, 2012. The seeds were sown at about $2 \mathrm{~cm}$ depth into plastic basins containing rice nursery culture soil. The rice seedlings were cultivated in a greenhouse to maintain the heat. The seedlings were irrigated in the late afternoon each day to maintain the soil water content. Upon reaching the three-leaf stage, the uniformly sized seedlings were selected and transplanted into plastic pots $(16.50 \mathrm{~cm}$ internal diameter $\times 16.50 \mathrm{~cm}$ depth $)$ on April 13, 2012. Each pot with only one seedling was placed directly into the experimental rice field. The planting density was $25.50 \mathrm{~cm} \times 24.50 \mathrm{~cm}$. The plants were fully watered throughout the crop growth cycle. Fertilizer was applied as follows: $165 \mathrm{~kg}$ nitrogen per hectare as urea, $180 \mathrm{~kg} \mathrm{~K} \mathrm{~K}_{2} \mathrm{O}$ per hectare as potassium chloride, and $90 \mathrm{~kg} \mathrm{P}_{2} \mathrm{O}_{5}$ per hectare as calcium magnesium phosphate. Basal dressing, tiller fertilizer, and panicle fertilizer were respectively supplied $2 \mathrm{~d}$ before transplantation, at $15 \mathrm{~d}$ after transplant, and at approximately $15 \mathrm{~d}$ to $20 \mathrm{~d}$ before heading (i.e., panicle differentiation stage). The proportion of basal dressing, tiller fertilizer, and panicle fertilizer was 4:2:4. Other field management, disease, and pest prevention were conducted using local conventional high-yield cultivation techniques. No major pests or diseases were noted.

High temperature treatment: Two different hightemperature treatments were performed inside a plant growth cabinet. Based on the characteristics of natural high temperature during summer season in double-rice cropping area, such as Jiangxi, Hunan, and Zhejiang provinces in central China, two temperature gradients (i.e., daily maximum temperature: $35^{\circ} \mathrm{C}$ and $38^{\circ} \mathrm{C}$ ) were set. The running days for high temperature treatment were $3 \mathrm{~d}$. The randomized rice plants that had essentially identical growth and development in the field pots were selected to tab labels at late panicledifferentiation stage. Each temperature treatment combination had six labelled plants. When the main and secondary tillers of the rice plants grew at the stage between full heading and grain filling period ( $7 \mathrm{~d}$ to $10 \mathrm{~d}$ after heading of $10 \%$ rice plants, i.e. early filling stage), all labelled random plants for two high-temperature treatments were transferred at 08:00 a.m. into the growth cabinet $(\mathrm{PRX}-1500 \mathrm{~B}$, internal size: length $1.91 \mathrm{~m} \times$ width $0.76 \mathrm{~m} \times$ height $1.83 \mathrm{~m}$, Shanghai Bilon Instruments Co., Ltd., China). The treatments and genotypes appeared randomized in the growth cabinet. The high-temperature treatment for Ganxin203 and Jinyou402 were from June 19 to June 22, whereas that for Zhong531 and E134 was from June 26 to June 29 and from June 29 to July 2 , respectively. The diurnal variation of air temperature was based on the temperature variation curve $1 \mathrm{~d}$ before simulation to control the high temperature in the programmable growth cabinet. The installations of other climatic factors for different high-temperature treatments in two plant growth cabinets were kept similar. The illumination time was $14 \mathrm{~h}$ based on weather conditions at that time. Lamps were balanced to ensure uniform flux densities throughout the cabinet. Illumination time, intensity, and relative humidity were kept unified during the treatment process.

The specific condition inside the plant growth cabinet was as follows. The duration of daily maximum temperature was maintained for $2 \mathrm{~h}$ (13:00 p.m. to 15:00 p.m., Beijing time). The diurnal range of temperature simulated the temperature variation curve as follows: daily minimum temperature was from 00:00 a.m. to 06:00 a.m. Then the temperature increased by $1^{\circ} \mathrm{C}$ per $1 \mathrm{~h}$ by 13:00 p.m. and high temperature was maintained until 15:00 p.m. The temperature gradually decreased by $1^{\circ} \mathrm{C}$ for $1 \mathrm{~h}$ increase between 15:00 p.m. and

Table 1. The setting of meteorological factors during high temperature treatment.

\begin{tabular}{|c|c|c|c|c|c|c|c|c|c|c|c|c|c|c|c|c|c|c|}
\hline \multirow{2}{*}{$\begin{array}{l}\text { Meteorological } \\
\text { factors }\end{array}$} & \multicolumn{18}{|c|}{ O' clock } \\
\hline & $\begin{array}{c}00: 00- \\
5: 00 \\
\end{array}$ & 6:00 & $7: 00$ & 8:00 & 9:00 & 10:00 & 11:00 & 12:00 & 13:00 & 14:00 & 15:00 & 16:00 & 17:00 & 18:00 & 19:00 & 20:00 & 21:00 & $\begin{array}{c}\text { 22:00- } \\
00: 00\end{array}$ \\
\hline \multirow[t]{2}{*}{$\mathrm{T}\left({ }^{\circ} \mathrm{C}\right)$} & 27 & 28 & 29 & 30 & 31 & 32 & 33 & 34 & 35 & 35 & 34 & 33 & 32 & 31 & 30 & 29 & 28 & 27 \\
\hline & 30 & 31 & 32 & 33 & 34 & 35 & 36 & 37 & 38 & 38 & 37 & 36 & 35 & 34 & 33 & 32 & 31 & 30 \\
\hline $\mathrm{RH}(\%)$ & 82 & 81 & 80 & 79 & 78 & 77 & 76 & 75 & 74 & 74 & 75 & 76 & 77 & 78 & 79 & 80 & 81 & 82 \\
\hline II $\left(\mu \mathrm{mol} \mathrm{m}^{-2} \mathrm{~s}^{-1}\right)$ & 0 & 324 & 324 & 324 & 432 & 432 & 540 & 540 & 540 & 540 & 540 & 432 & 432 & 324 & 324 & 0 & 0 & 0 \\
\hline
\end{tabular}

T: temperature; RH: relative humidity; II: illumination intensity. Two different high-temperature treatments $\left(35^{\circ} \mathrm{C}\right.$ and $\left.38^{\circ} \mathrm{C}\right)$ were conducted. The meteorological factors contained temperature, relative humidity and illumination intensity. Illumination time, intensity and relative humidity were kept similar for each treatment during treatment processing. Time (Beijing Time) was an automatic cycle every 24 hours. The duration for treatment was $3 \mathrm{~d}$. 
22:00 p.m. Then, the temperature returned to daily minimum temperature from 22:00 p.m. to 00:00 a.m. The setting programs of temperature were automatically repeated every $24 \mathrm{~h}$. The meteorological factors of high-temperature treatments are listed in Table 1.

Another 10 random pots of labelled plants in the paddy field was used as the control. The meteorological data in the experimental field were obtained from the agricultural meteorological station located within $1 \mathrm{~km}$ of the field. After high-temperature treatment, plants were immediately moved back to the rice field and removed the pots for natural growth. The temperature variation of high-temperature treatments and the controls in the field during treatment processing is described in Table 2. This table showed that the mean minimum temperature of all high-temperature treatments for the four early rice varieties was significantly higher than that of the control (all at $\mathrm{P}<0.01$ ). The mean daily temperature and mean maximum temperature of high-temperature treatments for Ganxin203 and Jinyou402 were obviously higher than those of the control (all at $\mathrm{P}<0.01$ ). The mean daily temperature and mean maximum temperature for $35^{\circ} \mathrm{C}$ treatments of Zhong531 and E134 were insignificant, whereas those for $38^{\circ} \mathrm{C}$ treatments were higher than those of the control.

Chlorophyll content [soil plant analysis development (SPAD value)]: Four second leaves from the top of main tillers (each from separate plant) were tagged for identification in each high-temperature treatment and the control. In addition, the leaf chlorophyll content of the four rice varieties was measured. Each SPAD value is the mean of three replicates determined from the central area of the second leaf from the top, with the SPAD-502 chlorophyll meter. The SPAD values were measured at around 10:00 a.m. at $1 \mathrm{~d}$ before the temperature treatment (i.e., background value) and at 0, 1, 4, 7 , and $10 \mathrm{~d}$ after the high-temperature treatment.
Yield and its components: After removing the abnormal rice plants, three replicates (three random plants) from each hightemperature treatment and the control were harvested individually at physiological maturity. The yield and its components of these plants were measured, including seed setting rate, unfilled grain rate, 1000-grain weight, plumpness, and single plant yield. All panicles were threshed by hand and their grain weights were recorded. The seed setting rate was estimated as the ratio of the number of filled grains to the total number of reproductive sites (grains) and expressed as a percentage. Each grain was pressed between the forefinger and thumb to separate the filled grains from the empty grains. The filled grains included both completely and partially filled grains (i.e., solid grains and unfilled grains). After withdrawing empty grains, the solid grains were separated from the unfilled grains by immersing in tap water. The grains that settled were the solid grains, whereas those that remained afloat were the unfilled grains. Plumpness was estimated as the ratio of average weight of the fertilized grains to the weight of the completely filled grains, with density above 1.0 .

Brown rice rate, milled rice rate and amylose content: The brown rice rate and the milled rice rate were determined for each temperature treatment and the controls using the standard method NY147-88 supplied by the Chinese Ministry of Agriculture. The grains were milled into brown rice using a JLGJ-4.5 type rice huller (Xinfeng, Food Instrument Factory, Taizhou, Zhejiang Province, China). The brown rice rate was estimated as the ratio of the average weight of brown rice to the weight of grain samples and expressed as percentage. The brown rice was milled into milled rice for $70 \mathrm{~s}$ using a JNMJ-3 type rice mill (Xinfeng). The milled rice rate was calculated as the ratio of the average weight of milled rice multiplied by the brown rice rate to the weight of samples from brown rice and expressed as a percentage. Amylose

Table 2. The temperature variation during high temperature treatment $\left({ }^{\circ} \mathrm{C}\right)$.

\begin{tabular}{lllllllllcc}
\hline Cultivar & Treatment & \multicolumn{3}{c}{ CK } & \multicolumn{4}{c}{ High temperature } & \multicolumn{3}{c}{ Mean daily temperature difference } \\
\cline { 3 - 10 } & & MDT & MAT & MIT & MDT & MAT & MIT & $\begin{array}{c}\text { MDT } \\
\text { difference }\end{array}$ & $\begin{array}{c}\text { MAT } \\
\text { difference }\end{array}$ & $\begin{array}{c}\text { MIT } \\
\text { difference }\end{array}$ \\
\hline Ganxin203 & $35^{\circ} \mathrm{C}$ & 26.73 & 31.33 & 22.68 & 30.33 & 35.00 & 28.00 & $3.61^{* *}$ & $3.68^{* *}$ & $5.33^{* *}$ \\
& $38^{\circ} \mathrm{C}$ & & & & 33.33 & 38.00 & 31.00 & $6.61^{* *}$ & $6.68^{* *}$ & $8.33^{* *}$ \\
Jinyou402 & $35^{\circ} \mathrm{C}$ & 26.73 & 31.33 & 22.68 & 30.33 & 35.00 & 28.00 & $3.61^{* *}$ & $3.68^{* *}$ & $5.33^{* *}$ \\
& $38^{\circ} \mathrm{C}$ & & & & 33.33 & 38.00 & 31.00 & $6.61^{* *}$ & $6.68^{* *}$ & $8.33^{* *}$ \\
Zhong531 & $35^{\circ} \mathrm{C}$ & 28.33 & 32.58 & 23.20 & 30.33 & 35.00 & 28.00 & 2.01 & 2.43 & $4.80^{* *}$ \\
& $38^{\circ} \mathrm{C}$ & & & & 33.33 & 38.00 & 31.00 & $5.01^{* *}$ & $5.43^{*}$ & $7.80^{* *}$ \\
E134 & $35^{\circ} \mathrm{C}$ & \multirow{2}{*}{30.35} & 35.15 & 25.23 & 30.33 & 35.00 & 28.00 & -0.02 & -0.15 & $2.78^{* *}$ \\
& $38^{\circ} \mathrm{C}$ & & & & 33.33 & 38.00 & 31.00 & $2.98^{* *}$ & $2.85^{* *}$ & $5.78^{* *}$ \\
\hline
\end{tabular}

MDT: mean daily temperature; MAT: mean maximum temperature; MIT: mean minimum temperature. Values followed by *or $* *$ are significantly different at 0.05 or 0.01 probability levels according to Student's t test, ns is non-significant, respectively. The temperature of the control was observed from the agricultural meteorological station located within $1 \mathrm{~km}$ of the field. Mean daily temperature difference was calculated as the remainder of the subtraction from the high temperature to the control. 
content was determined based on the methods in the national standard GB/T17891-1999 and GB7648-1987. The samples from milled rice were ground into powder using hammer cyclone grinding JXFM110 type (Shanghai Jiading Grain and Oil Equipment Co., Ltd., China) to measure the amylose content. The samples for measuring amylose content consisted of the polished powder after passing through $0.25 \mathrm{~mm}$ mesh. Amylose content was determined via the iodine blue colorimetric method with four replicates.

Other physiological components: During the grain filling stage, the flag leaf was detached at approximately $2 \mathrm{~cm}$ at 0 , 2 , and $4 \mathrm{~d}$ after the high-temperature treatment. The samples were immediately frozen in liquid nitrogen, and then stored at $-80^{\circ} \mathrm{C}$ for subsequent analysis. Physiological biochemical components were estimated using a ultraviolet-visible spectrophotometer TU-1810D type (Purkinje General Instrument Co., Ltd., Beijing, China), including soluble protein content (Coomassie brilliant blue method, G-250), Malondialdehyde (MDA) content (thiobarbituric acid method, TBA), and proline content. Each measurement was repeated thrice. The character stress index of all items under the high-temperature treatments was calculated as the ratio of the characteristic value under high temperature to that of the control.

Statistical analysis: The rice plants were harvested at maturity. All yield parameters, grain quality components, and physiological items were observed. The differences among the means for the plant growth cabinet and natural field experiments were analyzed using a Student's t-test (SPSS software ver. 17.0).

\section{RESULTS}

The seed setting rate, 1000-grain weight, plumpness, and single plant yield of the four early rice varieties declined under the high-temperature treatments, whereas their unfilled grain rate increased compared with that of the control during the early filling stage (Table 3 ). The variation range of the rice varieties increased when subjected to high-temperature treatment intensity. The high temperature responses of the yield components significantly differed among the different early rice varieties. Single plant yield of hybrid rice Jinyou402under high temperature was more affected than that of Ganxin203, whereas the effects on conventional rice E134 exceeded those on Zhong531. High temperature did not significantly affect the yield and components of Zhong531 compared with those in the control (except the unfilled grain rate). Hence, Zhong531 has high temperature tolerance. The high temperature treatments significantly decreased the single plant yield of Jinyou402 (35.98\%), Ganxin203 (21.03\%), and E134 (18.07\%) compared with the controls $(\mathrm{P}<0.05)$, which indicates that these genotypes are sensitive to high temperature. Meanwhile, the single plant yield of the four early rice varieties grown at $35^{\circ} \mathrm{C}$ showed slight decreases compared with those grown under the control conditions.

Similar to the influence of high temperature on yield components, the high temperature treatment also decreased the brown rice rate, milled rice rate, and amylose content, with the decline increasing with increasing temperature. The temperature responses of the brown rice rate, milled rice rate, and amylose content to were different among the four early rice varieties. The decrease in the brown rice rate, milled rice rate, and amylose content of Jinyou402 and Zhong531 at $35^{\circ} \mathrm{C}$ did not significantly differ from those of the control, which proved that the high temperature only caused slight heat injury (Table 4).

The chlorophyll content of the four early rice varieties in the controls gradually declined with time. After high-temperature treatment, the chlorophyll content in the second leaves from

Table 3. Effects of high-temperature treatment on grain yield and its components of early rice during the early filling stage.

\begin{tabular}{lllcccc}
\hline Cultivar & Treatment & $\begin{array}{c}\text { Seed setting } \\
\text { rate }(\%)\end{array}$ & $\begin{array}{c}\text { Unfilled grain } \\
\text { rate }(\%)\end{array}$ & $\begin{array}{c}\text { 1000-grain } \\
\text { weight }(\mathbf{g})\end{array}$ & $\begin{array}{c}\text { Yield per } \\
\text { plant }(\mathbf{g})\end{array}$ & $\begin{array}{c}\text { Plumpness } \\
(\%)\end{array}$ \\
\hline Ganxin203 & $\mathrm{CK}$ & $95.15 \pm 1.53 \mathrm{aA}$ & $6.07 \pm 1.32 \mathrm{aA}$ & $26.66 \pm 0.08 \mathrm{aA}$ & $25.78 \pm 0.63 \mathrm{aA}$ & $91.37 \pm 0.10 \mathrm{aA}$ \\
& $35^{\circ} \mathrm{C}$ & $76.49 \pm 2.14 \mathrm{bA}$ & $6.26 \pm 0.04 \mathrm{aA}$ & $26.45 \pm 0.05 \mathrm{aA}$ & $25.08 \pm 0.06 \mathrm{aA}$ & $79.66 \pm 2.08 \mathrm{bB}$ \\
& $38^{\circ} \mathrm{C}$ & $62.55 \pm 1.65 \mathrm{cB}$ & $6.99 \pm 0.52 \mathrm{aA}$ & $24.42 \pm 0.02 \mathrm{bB}$ & $20.36 \pm 2.65 \mathrm{bA}$ & $71.50 \pm 2.36 \mathrm{cB}$ \\
Jinyou402 & $\mathrm{CK}$ & $88.72 \pm 0.66 \mathrm{aA}$ & $7.91 \pm 1.05 \mathrm{aA}$ & $26.69 \pm 0.89 \mathrm{aA}$ & $26.97 \pm 1.11 \mathrm{aA}$ & $81.45 \pm 5.60 \mathrm{aA}$ \\
& $35^{\circ} \mathrm{C}$ & $76.74 \pm 0.57 \mathrm{bAB}$ & $10.48 \pm 2.44 \mathrm{aA}$ & $26.52 \pm 0.80 \mathrm{aA}$ & $22.38 \pm 2.33 \mathrm{aA}$ & $79.38 \pm 5.22 \mathrm{aA}$ \\
& $38^{\circ} \mathrm{C}$ & $73.94 \pm 2.83 \mathrm{bB}$ & $11.40 \pm 1.93 \mathrm{aA}$ & $26.48 \pm 0.42 \mathrm{aA}$ & $17.27 \pm 1.83 \mathrm{bB}$ & $74.59 \pm 5.00 \mathrm{aA}$ \\
Zhong531 & $\mathrm{CK}$ & $91.47 \pm 0.54 \mathrm{aA}$ & $12.24 \pm 3.32 \mathrm{aA}$ & $28.28 \pm 0.40 \mathrm{aA}$ & $18.61 \pm 2.08 \mathrm{aA}$ & $87.72 \pm 3.41 \mathrm{aA}$ \\
& $35^{\circ} \mathrm{C}$ & $88.88 \pm 0.52 \mathrm{aA}$ & $15.47 \pm 3.49 \mathrm{abA}$ & $25.94 \pm 0.34 \mathrm{aA}$ & $18.18 \pm 1.94 \mathrm{aA}$ & $85.29 \pm 0.97 \mathrm{aA}$ \\
& $38^{\circ} \mathrm{C}$ & $84.07 \pm 4.45 \mathrm{aA}$ & $20.39 \pm 1.34 \mathrm{bA}$ & $25.33 \pm 0.33 \mathrm{aA}$ & $17.59 \pm 2.11 \mathrm{aA}$ & $83.15 \pm 3.42 \mathrm{aA}$ \\
$\mathrm{E} 134$ & $\mathrm{CK}$ & $83.76 \pm 1.10 \mathrm{aA}$ & $19.93 \pm 1.44 \mathrm{aA}$ & $25.34 \pm 0.44 \mathrm{aA}$ & $19.04 \pm 1.06 \mathrm{aA}$ & $81.26 \pm 2.60 \mathrm{aA}$ \\
& $35^{\circ} \mathrm{C}$ & $76.66 \pm 1.83 \mathrm{aAB}$ & $23.56 \pm 0.38 \mathrm{aAB}$ & $22.65 \pm 0.15 \mathrm{abA}$ & $15.77 \pm 1.21 \mathrm{aA}$ & $76.01 \pm 1.88 \mathrm{aA}$ \\
& $38^{\circ} \mathrm{C}$ & $66.26 \pm 1.98 \mathrm{bB}$ & $25.01 \pm 1.49 \mathrm{bB}$ & $22.06 \pm 0.78 \mathrm{bA}$ & $15.60 \pm 0.61 \mathrm{bA}$ & $74.79 \pm 2.62 \mathrm{aA}$ \\
\hline
\end{tabular}

The data are means \pm standard error; data within the same column with the same letters indicate no significant difference at $1 \%$ or $5 \%$ level according to Student's t-test. 
Table 4. Effects of high-temperature treatment on brown rice rate, milled rice rate, and amylose content of early rice during the early filling stage.

\begin{tabular}{llllc}
\hline Cultivar & Treatment & $\begin{array}{c}\text { Brown rice rate } \\
(\boldsymbol{\%})\end{array}$ & $\begin{array}{c}\text { Milled rice rate } \\
(\boldsymbol{\%})\end{array}$ & $\begin{array}{c}\text { Amylose content } \\
(\boldsymbol{\%})\end{array}$ \\
\hline Ganxin203 & $\mathrm{CK}$ & $78.63 \pm 0.45 \mathrm{aA}$ & $66.86 \pm 0.84 \mathrm{aA}$ & $19.21 \pm 0.19 \mathrm{aA}$ \\
& $35^{\circ} \mathrm{C}$ & $76.90 \pm 0.37 \mathrm{aAB}$ & $61.47 \pm 0.65 \mathrm{bAB}$ & $16.69 \pm 0.32 \mathrm{cB}$ \\
& $38^{\circ} \mathrm{C}$ & $74.80 \pm 0.52 \mathrm{bB}$ & $58.48 \pm 1.13 \mathrm{bB}$ & $17.51 \pm 0.08 \mathrm{bB}$ \\
Jinyou402 & $\mathrm{CK}$ & $79.04 \pm 0.12 \mathrm{aA}$ & $65.58 \pm 0.78 \mathrm{aA}$ & $18.88 \pm 0.24 \mathrm{aA}$ \\
& $35^{\circ} \mathrm{C}$ & $77.51 \pm 0.33 \mathrm{aAB}$ & $63.73 \pm 1.55 \mathrm{aA}$ & $18.17 \pm 0.09 \mathrm{abA}$ \\
& $38^{\circ} \mathrm{C}$ & $73.94 \pm 0.39 \mathrm{bB}$ & $60.90 \pm 2.84 \mathrm{bA}$ & $17.84 \pm 0.24 \mathrm{bA}$ \\
Zhong531 & $\mathrm{CK}$ & $72.29 \pm 0.06 \mathrm{aA}$ & $64.87 \pm 0.24 \mathrm{aA}$ & $11.26 \pm 0.13 \mathrm{aA}$ \\
& $35^{\circ} \mathrm{C}$ & $69.74 \pm 0.26 \mathrm{abAB}$ & $62.77 \pm 0.15 \mathrm{aA}$ & $10.65 \pm 0.11 \mathrm{abAB}$ \\
& $38^{\circ} \mathrm{C}$ & $68.32 \pm 0.37 \mathrm{bB}$ & $58.12 \pm 0.76 \mathrm{bB}$ & $9.96 \pm 0.31 \mathrm{bB}$ \\
E134 & $\mathrm{CK}$ & $72.47 \pm 0.22 \mathrm{aA}$ & $61.37 \pm 0.34 \mathrm{aA}$ & $25.88 \pm 0.18 \mathrm{aA}$ \\
& $35^{\circ} \mathrm{C}$ & $71.69 \pm 0.23 \mathrm{aAB}$ & $60.97 \pm 0.28 \mathrm{aA}$ & $22.56 \pm 0.18 \mathrm{bB}$ \\
& $38^{\circ} \mathrm{C}$ & $70.82 \pm 0.13 \mathrm{bB}$ & $57.82 \pm 0.98 \mathrm{bB}$ & $22.48 \pm 0.06 \mathrm{bB}$ \\
\hline
\end{tabular}

The values are the mean of three replicates \pm standard error. Data within the same column with the same letters during each phase indicate no significant difference at $1 \%$ or $5 \%$ level according to Student's t-test. Amylose content was measured using the iodine colorimetric method with four replicates.
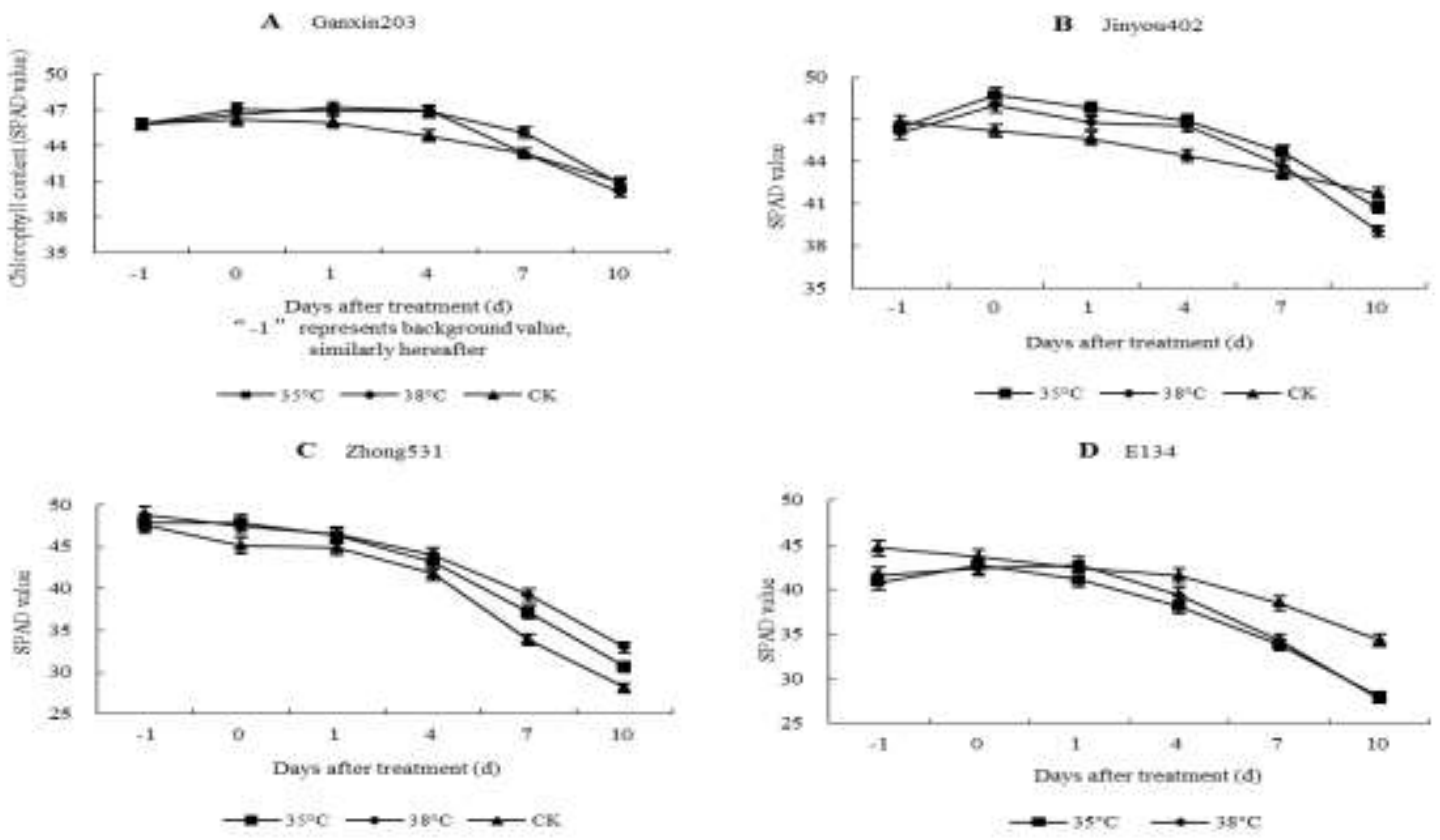

Figure 1.Dynamic changes of chlorophyll content (SPAD value) in early rice second leaves from the top after hightemperature treatment during the early filling stage. A: Ganxin203; B: Jinyou402; C: Zhong531; D: E134. SPAD value represents the chlorophyll content. "-1" on the abscissa represents background value. Diamond symbols represent the treatment of $35^{\circ} \mathrm{C}$, while square symbols and triangles represent the treatment of $38^{\circ} \mathrm{C}$ and $\mathrm{CK}$, respectively. Data are expressed as the mean of four replications.

the top of the plants increased within a narrow range. After ward, the chlorophyll content decreased compared with that of the control. At $10 \mathrm{~d}$ after high-temperature treatment, the chlorophyll content of two hybrid rice varieties was lower than that of the control, and the chlorophyll content at $35^{\circ} \mathrm{C}$ was higher than that at $38^{\circ} \mathrm{C}$ at the same time points. At $10 \mathrm{~d}$ after high-temperature treatment, the chlorophyll content of Ganxin203 in the control and the two treatments were significantly decreased $(\mathrm{P}<0.05)$. The SPAD of Jinyou 402 in the control was significantly decreased at $10 \mathrm{~d}$. By contrast, SPAD value was obviously lower at $7 \mathrm{~d}(\mathrm{P}<0.05)$, which clearly indicate that the effects of high temperature on 
Yang, Chen, Zhu, Peng, He, Fu, Bian, Hu, Ouyang \& He

Table 5. Effects of high-temperature treatment on proline content $(\mu \mathrm{g} / \mathrm{g} . \mathrm{FW})$ in early rice flag leaves during the early filling stage.

\begin{tabular}{|c|c|c|c|c|c|}
\hline \multirow[t]{2}{*}{ Cultivar } & \multirow[t]{2}{*}{ Treatment } & \multicolumn{3}{|r|}{ Days after treatment $(\mathrm{d})$} & \multirow{2}{*}{$\begin{array}{r}\text { Average } \\
\text { Treatment/CK }\end{array}$} \\
\hline & & & & 2 & \\
\hline \multirow[t]{3}{*}{ Ganxin203 } & $\mathrm{CK}$ & $26.97 \pm 0.07 \mathrm{cC}$ & $24.33 \pm 0.29 \mathrm{cB}$ & $22.62 \pm 0.42 \mathrm{cB}$ & \\
\hline & $35^{\circ} \mathrm{C}$ & $66.24 \pm 0.11 \mathrm{aA}$ & $39.46 \pm 0.99 \mathrm{aA}$ & $32.87 \pm 0.77 \mathrm{aA}$ & $1.84 \pm 0.31 \mathrm{aA}$ \\
\hline & $38^{\circ} \mathrm{C}$ & $35.40 \pm 0.50 \mathrm{bB}$ & $28.54 \pm 0.50 \mathrm{bB}$ & $27.65 \pm 0.32 \mathrm{bAB}$ & $1.24 \pm 0.04 \mathrm{aA}$ \\
\hline \multirow{3}{*}{ Jinyou402 } & $\mathrm{CK}$ & $28.40 \pm 0.36 \mathrm{bA}$ & $24.76 \pm 0.14 \mathrm{aA}$ & $22.76 \pm 0.43 \mathrm{aA}$ & \\
\hline & $35^{\circ} \mathrm{C}$ & $34.11 \pm 0.07 \mathrm{aA}$ & $22.69 \pm 0.07 \mathrm{bB}$ & $19.69 \pm 0.09 \mathrm{aA}$ & $0.99 \pm 0.10 \mathrm{aA}$ \\
\hline & $38^{\circ} \mathrm{C}$ & $34.54 \pm 0.07 \mathrm{aA}$ & $23.19 \pm 0.15 b B$ & $20.83 \pm 0.53 \mathrm{aA}$ & $1.02 \pm 0.10 \mathrm{aA}$ \\
\hline \multirow[t]{3}{*}{ Zhong531 } & $\mathrm{CK}$ & $26.83 \pm 0.07 \mathrm{cC}$ & $24.90 \pm 0.57 \mathrm{aA}$ & $15.83 \pm 0.22 \mathrm{bA}$ & \\
\hline & $35^{\circ} \mathrm{C}$ & $32.61 \pm 0.15 \mathrm{aA}$ & $17.55 \pm 0.04 \mathrm{bB}$ & $17.33 \pm 0.86 \mathrm{abA}$ & $1.00 \pm 0.16 \mathrm{aA}$ \\
\hline & $38^{\circ} \mathrm{C}$ & $29.19 \pm 0.29 b B$ & $22.69 \pm 0.83 \mathrm{aAB}$ & $19.26 \pm 0.36 \mathrm{aA}$ & $1.07 \pm 0.09 \mathrm{aA}$ \\
\hline \multirow[t]{3}{*}{ E134 } & $\mathrm{CK}$ & $24.76 \pm 0.14 \mathrm{aA}$ & $21.62 \pm 0.12 \mathrm{aA}$ & $18.83 \pm 0.50 \mathrm{aA}$ & \\
\hline & $35^{\circ} \mathrm{C}$ & $20.40 \pm 0.21 \mathrm{bB}$ & $20.26 \pm 0.36 \mathrm{aA}$ & $15.26 \pm 0.78 \mathrm{aA}$ & $0.86 \pm 0.04 \mathrm{aA}$ \\
\hline & $38^{\circ} \mathrm{C}$ & $19.40 \pm 0.50 \mathrm{bB}$ & $17.69 \pm 0.07 \mathrm{aA}$ & $12.48 \pm 0.42 \mathrm{aA}$ & $0.75 \pm 0.05 \mathrm{aA}$ \\
\hline
\end{tabular}

The values are the mean of three replicates \pm standard error. Data within the same column with the same letters during each phase indicate no significant difference at $1 \%$ or $5 \%$ level according to Student's t-test.

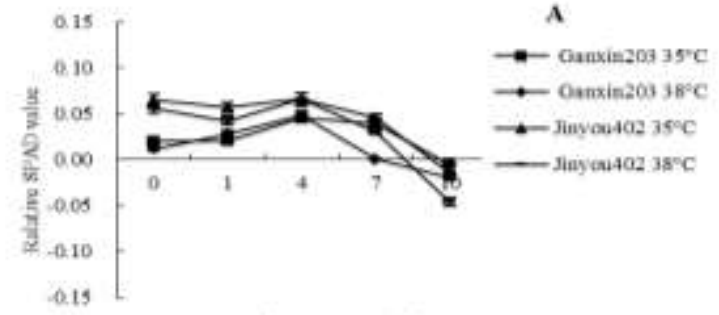

Doys after treatmeet (d)

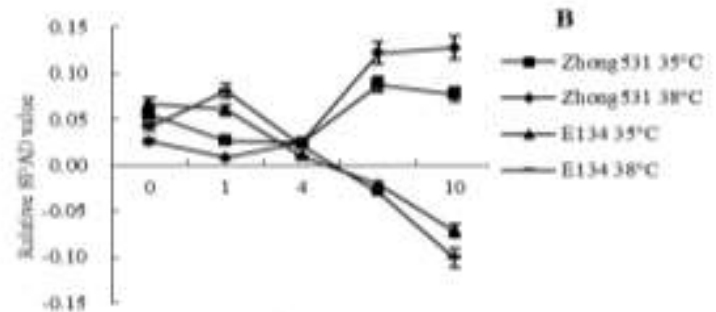

Days after treatinent (d)

Figure 2. Dynamic changes in relative chlorophyll content (SPAD value) in the second leaves of the early rice after high-temperature treatment during the early filling stage. A: Ganxin203 and Jinyou402; B: Zhong531 and E134. Relative chlorophyll content $=$ [(SPAD value of treatment - background value of the treatment $)$ (SPAD value of the CK - background value of the CK)]/CK SPAD value. Average values from four independent measurements are shown with error bars.

Jinyou402 is greater than that on Ganxin203 (Fig. 1A and B). The chlorophyll content of the control and two conventional rice varieties in the treatments were lower than those of the two hybrid rice varieties, which indicates that the functional period of the leaves in conventional rice is shorter than that of the hybrid rice. The chlorophyll content of the conventional rice variety E134 was generally low, and the background value at $38^{\circ} \mathrm{C}$ was higher than that at $35^{\circ} \mathrm{C}$, causing the chlorophyll content at $35^{\circ} \mathrm{C}$ to be lower than that at $38^{\circ} \mathrm{C}$ at the same time point. However, the chlorophyll content of the conventional rice variety Zhong531 ripened under high temperature was always higher than that of the control, which demonstrates that E143 is more sensitive to high temperature than Zhong531 (Fig. $1 \mathrm{C}$ and D).

The changes in relative chlorophyll content (SPAD value) in the four early rice varieties after the high-temperature treatment are shown in Figure 2. To reduce the effects of background, the relative chlorophyll content was calculated as the relative SPAD value $=[(\mathrm{SPAD}$ value of treatment - background value of treatment) - (SPAD value of CK background value of CK)]/CK SPAD value. The results showed that the relative chlorophyll content of Ganxin203 and Jinyou 402 was above zero $(\mathrm{P}<0.05)$ within $7 \mathrm{~d}$ after the high-temperature treatment, which suggest that chlorophyll content increased within a narrow range. At $10 \mathrm{~d}$ after hightemperature treatment, the chlorophyll content of Ganxin203 and Jinyou 402 was lower than that of the control, which is consistent with the changes in the relative chlorophyll content. The relative chlorophyll content of the two hybrid rice varieties was also higher at $35^{\circ} \mathrm{C}$ than at $38^{\circ} \mathrm{C}$ (Fig. $2 \mathrm{~A}$ ). The relative changes in chlorophyll content in E134 were similar to that of the two hybrid rice varieties, and was less than zero at $7 \mathrm{~d}$ after the high-temperature treatment. By contrast, the high-temperature treatment during early filling stage positively affected the relative chlorophyll content of Zhong531 (with the content always greater than zero). This finding suggests that Zhong531 tolerates the high temperature (Fig. 2B). 
Table 5 shows the proline content of all treatments and the controls in the four early rice flag leaves gradually declined with the growth period. Proline content significantly differed among the four early rice varieties in response to high temperature stress. After high-temperature treatment, the proline content of Ganxin203 was always significantly greater than that of the control. At $0 \mathrm{~d}$ after high-temperature treatment, the proline content in Jinyou402 flag leaves was significantly higher than that of the control, but became lower than that of the control thereafter. The proline content in Zhong531 only changed slightly, but continuously deceased in E134 compared with the control. This finding indicates that E134 is heat tolerant. The proline content in Jinyou402 and
Zhong531 under the $35^{\circ} \mathrm{C}$ treatment was lower than that under the $38^{\circ} \mathrm{C}$ treatment (Table 5).

Generally, the soluble protein content in rice flag leaves during the grain filling stage gradually declined with growth period progression. As shown in Table 6, the soluble protein content of all treatments and the controls decreased, with the decline in soluble protein content after high-temperature treatment higher with the treatment ratio to $\mathrm{CK}$ higher than zero (except Ganxin 203 at $35^{\circ} \mathrm{C}$ ). The most prominent decrease was in Jinyou402, with an average decrease in soluble protein content of $17.16 \%$ after the high-temperature treatment during the early filling stage.

The changes in MDA content in the control during the early

Table 6. Effects of high-temperature treatment on soluble protein content $(\mathrm{mg} / \mathrm{g}$. FW) in the flag leaves of early rice during the early filling stage.

\begin{tabular}{llcccc}
\hline Cultivar & Treatment & \multicolumn{3}{c}{ Days after treatment (d) } & Average \\
\cline { 2 - 5 } & & \multicolumn{1}{c}{$\mathbf{0}$} & $\mathbf{2}$ & 4 & \\
\hline Ganxin203 & $\mathrm{CK}$ & $1.24 \pm 0.03 \mathrm{bB}$ & $1.00 \pm 0.01 \mathrm{bB}$ & $0.90 \pm 0.00 \mathrm{bB}$ & \\
& $35^{\circ} \mathrm{C}$ & $2.24 \pm 0.07 \mathrm{aA}$ & $2.18 \pm 0.01 \mathrm{aA}$ & $2.14 \pm 0.01 \mathrm{aA}$ & $2.12 \pm 0.17 \mathrm{aA}$ \\
& $38^{\circ} \mathrm{C}$ & $0.93 \pm 0.07 \mathrm{cC}$ & $0.90 \pm 0.05 \mathrm{cC}$ & $0.58 \pm 0.07 \mathrm{cC}$ & $0.76 \pm 0.08 \mathrm{bB}$ \\
Jinyou402 & $\mathrm{CK}$ & $1.18 \pm 0.03 \mathrm{aA}$ & $1.16 \pm 0.05 \mathrm{aA}$ & $1.13 \pm 0.04 \mathrm{aA}$ & \\
& $35^{\circ} \mathrm{C}$ & $0.96 \pm 0.02 \mathrm{bA}$ & $0.91 \pm 0.03 \mathrm{bA}$ & $0.87 \pm 0.06 \mathrm{bA}$ & $0.79 \pm 0.01 \mathrm{aA}$ \\
& $38^{\circ} \mathrm{C}$ & $1.19 \pm 0.05 \mathrm{aA}$ & $0.92 \pm 0.04 \mathrm{bA}$ & $0.89 \pm 0.02 \mathrm{abA}$ & $0.86 \pm 0.07 \mathrm{aA}$ \\
Zhong531 & $\mathrm{CK}$ & $1.41 \pm 0.02 \mathrm{aA}$ & $1.26 \pm 0.16 \mathrm{aA}$ & $0.98 \pm 0.03 \mathrm{aA}$ & \\
& $35^{\circ} \mathrm{C}$ & $1.09 \pm 0.00 \mathrm{bB}$ & $1.02 \pm 0.00 \mathrm{aA}$ & $0.72 \pm 0.10 \mathrm{aA}$ & $0.77 \pm 0.04 \mathrm{aA}$ \\
& $38^{\circ} \mathrm{C}$ & $1.14 \pm 0.04 \mathrm{bB}$ & $1.01 \pm 0.02 \mathrm{aA}$ & $0.97 \pm 0.01 \mathrm{aA}$ & $0.87 \pm 0.10 \mathrm{aA}$ \\
& $\mathrm{CK}$ & $1.23 \pm 0.02 \mathrm{aA}$ & $1.13 \pm 0.05 \mathrm{aA}$ & $1.00 \pm 0.03 \mathrm{aA}$ & \\
& $35^{\circ} \mathrm{C}$ & $1.23 \pm 0.01 \mathrm{aA}$ & $1.02 \pm 0.07 \mathrm{aA}$ & $1.00 \pm 0.12 \mathrm{aA}$ & $0.97 \pm 0.03 \mathrm{aA}$ \\
& $38^{\circ} \mathrm{C}$ & $0.89 \pm 0.02 \mathrm{bB}$ & $1.02 \pm 0.04 \mathrm{aA}$ & $1.15 \pm 0.01 \mathrm{aA}$ & $0.93 \pm 0.13 \mathrm{aA}$ \\
\hline
\end{tabular}

The values are the mean of three replicates \pm standard error. Data within the same column with the same letters during each phase indicate no significant difference at $1 \%$ or $5 \%$ level according to Student's t-test. The soluble protein content was determined using the Coomassie brilliant blue method (G-250).

Table 7. Effects of high-temperature treatment on MDA content (nmol/g FW) in early rice flag leaves during the early filling stage.

\begin{tabular}{llcccc}
\hline Cultivar & Treatment & \multicolumn{3}{c}{ Days after treatment (d) } & Average \\
\cline { 2 - 5 } & & $\mathbf{0}$ & $\mathbf{2}$ & $\mathbf{4}$ & Treatment/CK \\
\hline Ganxin203 & $\mathrm{CK}$ & $10.85 \pm 0.25 \mathrm{aA}$ & $12.70 \pm 0.08 \mathrm{aA}$ & $13.65 \pm 0.26 \mathrm{aA}$ & \\
& $35^{\circ} \mathrm{C}$ & $8.43 \pm 0.40 \mathrm{bA}$ & $10.24 \pm 0.12 \mathrm{bB}$ & $10.75 \pm 0.14 \mathrm{bB}$ & $0.79 \pm 0.01 \mathrm{bA}$ \\
& $38^{\circ} \mathrm{C}$ & $10.71 \pm 0.83 \mathrm{abA}$ & $11.36 \pm 0.05 \mathrm{bB}$ & $12.60 \pm 0.45 \mathrm{aAB}$ & $0.93 \pm 0.02 \mathrm{aA}$ \\
Jinyou402 & $\mathrm{CK}$ & $11.31 \pm 0.20 \mathrm{aA}$ & $12.81 \pm 0.23 \mathrm{aA}$ & $13.44 \pm 0.14 \mathrm{aA}$ & \\
& $35^{\circ} \mathrm{C}$ & $12.15 \pm 0.09 \mathrm{aA}$ & $13.01 \pm 0.22 \mathrm{aA}$ & $13.72 \pm 0.16 \mathrm{aA}$ & $0.96 \pm 0.01 \mathrm{aA}$ \\
& $38^{\circ} \mathrm{C}$ & $11.96 \pm 0.10 \mathrm{aA}$ & $13.22 \pm 0.38 \mathrm{aA}$ & $13.93 \pm 0.41 \mathrm{aA}$ & $1.00 \pm 0.01 \mathrm{aA}$ \\
Zhong531 & $\mathrm{CK}$ & $10.45 \pm 0.10 \mathrm{aA}$ & $12.13 \pm 0.10 \mathrm{aA}$ & $11.86 \pm 0.32 \mathrm{aA}$ & \\
& $35^{\circ} \mathrm{C}$ & $10.75 \pm 0.07 \mathrm{aA}$ & $9.85 \pm 0.14 \mathrm{bB}$ & $8.54 \pm 0.07 \mathrm{bB}$ & $0.85 \pm 0.09 \mathrm{aA}$ \\
& $38^{\circ} \mathrm{C}$ & $8.77 \pm 0.32 \mathrm{bA}$ & $8.92 \pm 0.09 \mathrm{cB}$ & $10.83 \pm 0.21 \mathrm{aAB}$ & $0.83 \pm 0.05 \mathrm{aA}$ \\
& $\mathrm{CK}$ & $13.88 \pm 0.10 \mathrm{aA}$ & $14.81 \pm 0.30 \mathrm{aA}$ & $16.68 \pm 0.28 \mathrm{aA}$ & \\
& $35^{\circ} \mathrm{C}$ & $11.40 \pm 0.15 \mathrm{cB}$ & $13.15 \pm 0.49 \mathrm{aA}$ & $13.44 \pm 0.70 \mathrm{bA}$ & $0.84 \pm 0.03 \mathrm{aA}$ \\
& $38^{\circ} \mathrm{C}$ & $12.66 \pm 0.09 \mathrm{bA}$ & $13.18 \pm 0.53 \mathrm{aA}$ & $14.35 \pm 0.25 \mathrm{abA}$ & $0.89 \pm 0.02 \mathrm{aA}$ \\
\hline
\end{tabular}

The values are the mean of three replicates \pm standard error. Data within the same column with the same letters during each phase indicate no significant difference at $1 \%$ or $5 \%$ level according to Student's t-test. The soluble protein content was determined using the thiobarbituric acid method (TBA). 
filling stage indicated that the MDA content of early rice flag leaves gradually increased, and decreased after hightemperature treatment (Table 7). The MDA content of the flag leaves was more influenced by the $35^{\circ} \mathrm{C}$ treatment than the $38^{\circ} \mathrm{C}$ treatment during the grain filling stage. Meanwhile, the two high-temperature treatments did not significantly affect the MDA content of Zhong531, with an average decrease of $15.40 \%$ in the $35^{\circ} \mathrm{C}$ treatment and $17.19 \%$ in the $38^{\circ} \mathrm{C}$ treatment, respectively. This result suggests that Zhong531 was tolerant to high temperature.

\section{DISCUSSION}

Transient or sustained high temperature causes a series of changes that affect plant growth and development. Although rice plants can withstand certain heat stress, most reports provide direct evidence of decreased rice yield and grain quality because of the increased temperature (Huang et al., 2016). The negative effects on rice plant caused by high temperature were a result of decreased spikelet fertility, faster grain filling, fewer filled grains, and lower grain weight, which affect grain yield and quality during the grain filling stage (Prasad et al., 2006; Mohammed and Tarpley, 2009b; Lin et al., 2010; Fahad et al., 2016). Rice grains ripened under high temperature exhibited low weights, chalky appearance, and low amylose content (Yamakawa et al., 2007; Mitsui et al., 2013). Our findings demonstrated that yield components, including seed setting rate, 1000-grain weight, plumpness, and grain quality, as well as brown rice rate, milled rice rate, and amylose content of rice declined under high temperature compared with those under the control. The heat damage at $38^{\circ} \mathrm{C}$ on early rice, as measured in terms of yield components, was greater than that at $35^{\circ} \mathrm{C}$ treatment. The differences in mean daily temperature and mean maximum temperature in E134 at $34^{\circ} \mathrm{C}$ were negative, whereas the mean minimum temperature (i.e., night time temperature) was obviously higher than that of the control thereby, decreasing the yield. In the present study, significant genotypic differences were observed between high temperature responses to yield components among different rice varieties. The influence of high temperature on the hybrid rice Jinyou 402 was more than that on Ganxin203, and the influence on the conventional rice E134 exceeded that on Zhong531.

In the current study, we found the effects of high temperature on physiological parameters of rice flag leaves were consistent with the influence on yield components and grain quality. High temperature negatively affected chlorophyll content, and the decreased rate of chlorophyll content in heattolerant varieties was lower than that in heat-sensitive varieties (Mohammed and Tarpley, 2009a). In the present research, the chlorophyll content of rice increased within a narrow range under high temperature, and then decreased compared with the control. Meanwhile, the effect of high temperature on the hybrid rice Jinyou402 was greater than that on Ganxin203. Previous studies have shown that high temperature could break the balance of starch content, protein storage in mature grains, reactive oxygen species, antioxidant enzyme activity, and proline content in rice leaves (Morita $e t$ al., 2005; Fitzgerald and Resurreccion, 2009; Hasanuzzaman et al., 2013). Proline, as a plant osmotic regulator, protects the membrane and enzyme activity under abiotic stress (Cha-um and Kirdmanee, 2008). Our findings clearly indicate that Jinyou402 had lower proline content than those of Ganxin203 under high temperature. By contrast, the proline content of the conventional rice variety E134 was lower than that of the control, which indicates that E134 is sensitive to heat. Proteins are important to plant life activities. Soluble protein plays a highly protective role in plants that are exposed to abiotic stresses (Yamakawa and Hakata, 2010). High temperature improved enzyme activity during source-sink transportation and enhanced leaf protein synthesis, which accelerated leaf soluble protein transport to the grains and promoted grain protein synthesis thereby, lowering the soluble protein levels in the leaves. In the present study, the soluble protein content of the flag leaves of the four early rice varieties decreased under high temperature.

Different rice varieties exhibit different responses to hightemperature stress. Based on decreases in spikelet fertility under high temperature, N22, IR64, BKN6624-46-2, Nipponbare and Huanghuazhan were heat-tolerant cultivars, whereas Shuanggui 1, Akitakomachi, Minamihikari, Koshihikari, IR-8, and Hinohikari were heat-sensitive cultivars (Prasad et al., 2006; Cao et al., 2009; Jagadish et al., 2010; Chen et al., 2011). The japonica varieties Koshiibuki and Tentakaku produced less chalky grains under high temperature (high temperature tolerant), whereas Hatsuboshi and Sasanishiki produced severely chalky grains (high temperature sensitive) (Yamakawa et al., 2007). Our results indicated that Zhong531with higher seed setting, 1000-grain weight and yield was heat tolerant, while E134 was susceptible to high temperature. The heat tolerance of rice is related to in vivo reactive oxygen generation, membrane lipid peroxidation, as well as the balance between removal and defense mechanism. Huanghuazhan with higher yield had stronger oxidation and antioxidant protection capability in the roots, and higher adenosine triphosphate enzyme activity in rice grains under high temperature (Cao et al., 2009). Yangdao 6 maintained higher chlorophyll content, free proline content, soluble protein content, and lower MDA content, which may contribute to greater heat resistance (Xie et al., 2012). In the present work, we demonstrated that Zhong531 had higher chlorophyll content, proline content, soluble protein, and lower MDA content, which may be important for maintaining its high yield under high temperature during the early filling stage.

Conclusion: In conclusion, the yield components of different early varieties in response to high temperature exhibited 
significant genotypic differences. The influence of high temperature on the hybrid rice variety Jinyou402 was greater than that on Ganxin203, and the influence of high temperature on the conventional rice variety E134 was greater than that on Zhong531. The influences of high temperature on the physiological parameters of flag leaves were consistent with the influence on yield components and grain quality.

Acknowledgements: This research is supported by the Special Scientific Research Found of Meteorology in the Public Welfare Profession of China (Grant No: GYHY201406025 and GYHY201006025), the Jiangxi Meteorological Technology Foundation (JMTF20170221), the Youth Talent Training Found of Jiangxi Meteorological Bureau (YTTF201603), and the Climate Change Special Found of China Meteorological Administration (CCSF201513).

\section{REFERENCES}

Cantrell, R.P. and T.G. Reeves. 2002. The rice genome: the cereal of the world's poor takes center stage. Science. 296 : 53.

Cao, Y.Y., H. Duan, L.N. Yang, Z.Q. Wang, L.J. Liu and J.C. Yang. 2009. Effect of high temperature during heading and early grain filling on grain yield of Indica rice cultivars differing in heat-tolerance and its physiological mechanism. Acta. Agron. Sinica 35:512-521. (In Chinese)

Cha-um, S. and C. Kirdmanee. 2008. Effect of osmotic stress on proline accumulation, photosynthetic abilities and growth of sugarcane plantlets (Saccharum officinarum L.). Pak. J. Bot. 40:2541-2552.

Chen, X., W. Zhang, B. Zhang, J. Zhou, Y. Wang, Q. Yang, Y. Ke and H. He. 2011. Phosphoproteins regulated by heat stress in rice leaves. Prot. Sci. 9:1-9.

Cooper, N.T.W., T.J. Siebenmorgen and P.A. Counce. 2008. Effects of nigh ttime temperature during kernel development on rice physicochemical properties. Cereal. Chem. 85:276-282.

El-Kereamy, A., Y.M. Bi, K. Ranathunge, P.H. Beatty, A.G. Good and S.J. Rothstein. 2012. The rice R2R3-MYB transcription factor OsMYB55 is involved in the tolerance to high temperature and modulates amino acid metabolism. PLoS. One. 7: e52030.

Fahad, S., S. Hussain, S. Saud, S. Hassan, Z. Ihsan, A.N. Shah, C. Wu, M. Yousaf, W. Nasim, H. Alharby, F. Alghabari and J. Huang. 2016. Exogenously applied plant growth regulators enhance the morpho-physiological growth and yield of rice under high temperature. Front. Plant. Sci. 7:1250.

Fitzgerald, M.A and A.P. Resurreccion. 2009. Maintaining the yield of edible rice in a warming world. Funct. Plant. Biol. 36:1037-1045.

Han, F., H. Chen, X.J. Li, M.F. Yang, G.S. Liu and S.H. Shen. 2009. A comparative proteomic analysis of rice seedlings under various high-temperature stresses. BBA-Proteins Proteom. 1794:1625-1634.

Hasanuzzaman, M., K. Nahar, M.M. Alam, R. Roychowdhury and M. Fujita. 2013. Physiological, biochemical, and molecular mechanisms of heat stress tolerance in plants. Int. J. Mol. Sci. 14:9643-9684.

Huang, M., R. Zhang, P. Jiang, X. Xie, X. Zhou, F. Cao and Y. Zou. 2016. Temperature-related yield constraints of early-rice in south china: A cross-location analysis. PloS. One. 11: e0158601.

Jagadish, S.V., P.Q. Craufurd and T.R. Wheeler. 2007. High temperature stress and spikelet fertility in rice (Oryza sativa L.). J. Exp. Bot. 58:1627-1635.

Jagadish, S.V., R. Muthurajan, R. Oane, T.R. Wheeler, S. Heuer, J. Bennett and P.Q. Craufurd. 2010. Physiological and proteomic approaches to address heat tolerance during anthesis in rice (Oryza sativa L.). J. Exp. Bot. 61:143-156.

Liao, J.L., H.W. Zhou, H.Y. Zhang, P.A. Zhong and Y.J. Huang. 2014. Comparative proteomic analysis of differentially expressed proteins in the early milky stage of rice grains during high temperature stress. J. Exp. Bot. 65:655-671.

Lin, C.J., C.Y. Li, S.K. Lin, F.H. Yang, J.J. Huang, Y.H. Liu and H.S. Lur. 2010. Influence of high temperature during grain filling on the accumulation of storage proteins and grain quality in rice (Oryza sativa L.). J. Agr. Food. Chem. 58:10545-10552.

Madan, P., S.V. Jagadish, P.Q. Craufurd, M. Fitzgerald, T. Lafarge and T.R. Wheeler. 2012. Effect of elevated $\mathrm{CO}_{2}$ and high temperature on seed-set and grain quality of rice. J. Exp. Bot. 63:3843-3852.

Kim, H.Y., J. Ko, S. Kang and J. Tenhunen. 2013. Impacts of climate change on paddy rice yield in a temperate climate. Glob. Chang. Biol. 19:548-562.

Mitsui, T., T. Shiraya, K. Kaneko and K. Wada. 2013. Proteomics of rice grain under high temperature stress. Plant. Sci. 4: 36.

Mohammed, A.R. and L. Tarpley. 2009a. High night time temperatures affect rice productivity through altered pollen germination and spikelet fertility. Agr. Forest. Meteorol. 149: 999-1008.

Mohammed, A.R. and L. Tarpley. 2009b. Instrumentation enabling study of plant physiological response to elevated night temperature. Plant Meth. 5:1-10.

Morita, S., J. Yonemaru and J. Takanashi. 2005. Grain growth and endosperm cell size under high night temperatures in rice (Oryza sativa L.). Ann. Bot. 95:695-701.

Peng, S.B., J. Huang, J.E. Sheehy, R.C. Laza, R.M. Visperas, X. Zhong, G.S. Centeno, G.S. Khush and K.G. Cassman. 2004. Rice yields decline with higher night temperature from global warming. Proc. Natl. Acad. Sci. 101:99719975. 
Prasad, P.V.V., K.J. Boote, J.L.H. Allen, J.E. Sheehy and J.M.G. Thomas. 2006. Species, ecotype and cultivar differences in spikelet fertility and harvest index of rice in response to high temperature stress. Field Crop Res. 95:398-411.

Rahman, M.A., A. Saboor, I.A. Baig, U. Shakoor and H. Kanwal. 2017. An investigation of the impact of climate change on rice crop in Pakistan: A multivariate analysis. Pak. J. Agri. Sci. 54:561-566.

Ray, D.K., J.S. Gerber, G.K. MacDonald and P.C. West. 2015. Climate variation explains a third of global crop yield variability. Nat. Comm. 6:5989.

Schiermeier, Q. 2015. Quest for climate-proof farms. Nature. 523:396-397.
Walbot, V. 2011. How plants cope with temperature stress. BMC Biol. 9:79.

Xie, X.J., B.B. Li and S.H. Shen. 2012. Impact of high temperature stress on photosynthetic characteristic and yield of rice (Oryza sativa) at heading. Ind. J. Agric. Sci. 82:516.

Yamakawa, H. and M. Hakata. 2010. Atlas of rice grain filling-related metabolism under high temperature: joint analysis of metabolome and transcriptome demonstrated inhibition of starch accumulation and induction of amino acid accumulation. Plant Cell Physiol. 51:795-809.

Yamakawa, H., T. Hirose, M. Kuroda and T. Yamaguchi. 2007. Comprehensive expression profiling of rice grain fillingrelated genes under high temperature using DNA microarray. Plant Physiol. 144:258-277. 